Central America. The bibliography offers useful hints about relevant background reading materials for such negotiations. The future of economic integration or cooperation in Central America is of course dependent on the emergence of regional political stability.

\title{
INFORMATICS LAW
}

A commission has been established by the Intergovernmental Bureau for Informatics (located at 23, viale Civilta del Lavoro, 00144 Rome, Italy) to study the application of computer and other technology to legal information research (named by the Bureau as "informatics law" which is based on the French word "informatique") and the regulation by law of information data production and use.

The commission has recently issued a report on the Considerations for the Study of Informatics Law (Intergovernmental Bureau for Informatics Documents on Informatics Law, Orange Series, DR. 01) which contains the outline of an ambitious international program for cooperation in the development of retrieval technologies for legal information, as well as recommendations for a suitable international legal regime dealing with the distribution of information. Discussion of these issues will be given a prominent place in the program of the $2 \mathrm{~d}$ Intergovernmental Conferences on Informatics Strategies and Policies, organized by the Intergovernmental Bureau for Informatics for mid-1983.

\section{NEW COMPANIES LEGISLATION IN AUSTRALIA}

On 18 June 1981 the Companies Act 1981 (no. 89 of 1981) was assented to by the Australian Parliament. (Available from A.G.P.S., Canberra, A.C.T., Australia, 2600. Cat. no. 81 41174. Price: A\$ 15.20). The Act is expected to come into operation early in 1982. Nine Acts associated with the new national companies and securities legislation also received assent on 18 June 1981. New regulations under these Acts have also been made.

The best advice one can give to the foreign law librarian, who has an interest in Australian companies and securities law is to suggest that he/she subscribe to $\mathrm{CCH}$ Australia Limited's Australian Company Law and Practice. This new service will replace the $\mathrm{CCH}$ Australian Corporate Affairs Reporter by early 1982. The first volume of the ACLP is already available and contains the full text of all the relevant Acts together with practical commentary. The second loose-leaf volume is expected to be issued in December 1981 containing detailed explanations of the new legislation. 